\title{
Structural Changes in the Kitakyushu Eco-Town Initiative Based on a Multi-Year Survey of Materials Flow
}

\author{
Tadashi Tsuruta, Yuki Honda, Atsushi Fujiyama, and Toru Matsumoto
}

\begin{abstract}
In this study, the change of the material flow involved in Kitakyushu Eco-town and the factor of distance according to substance are analyzed along with the result of the material flow investigation over multiple years. Furthermore, this can be deleted the rate of reduction for natural resources, the rate of usage for energy and the rate of reduction for final disposal are also analyzed. The subjects of this research are 18 enterprises located in Kitakyushu Eco-town in 2005 and 23 enterprises located in Kitakyushu Eco-town in 2010. The results show that not only material flow and haul distance but also environmental indicators were changed by companies located in Eco-town.
\end{abstract}

Index Terms-Kitakyushu eco-town, material flow, resources circulation, transition.

\section{RESEARCH BACKGROUND AND OBJECTIVES}

Industrial symbiosis is the concept which involves a collective approach to competitive advantage through the physical exchange of materials, energy, water and/or byproducts, or the shared use of assets, logistics and information. Regarding this concept, many cases have been reported around the world [1]-[7]. The Eco-town Initiative which was discussed in this paper is positioned in one of the types of industry symbiosis.

The Eco-town Initiative, begun in 1997, has gained acceptance in 26 regions throughout Japan and has exhibited continuing progress in the project's activities, particularly the reuse and recycling of waste products and production by-products. Based on the 2008 "Second Plan for Promoting the Establishment of a Recycling Society," the initiative takes its place in the national effort to build a recycling society carried out regionally, and Eco-town encompasses a particularly wide area of activities related to materials circulation. In order to increase the functionality of Eco-town as an effective basis for resource circulation, it is essential to grasp and analyze the situation in terms of environmental, social, and economic aspects. However, it cannot yet be claimed that actual conditions have been precisely grasped. After more than 18 years of activity, the changes in

Manuscript received November 26, 2015; revised March 21, 2016. This work was supported in part by the Environmental Bureau of the city government of Kitakyushu.

T. Tsuruta is with Environmental Technology Service Co., Ltd., Kitakyushu, 804-0003 Japan (e-mail: tsuruta_tadshi@kan-tec.co.jp).

Y. Honda and T. Matsumoto are with the University of Kitakyushu, Kitakyushu, 808-0135, Japan (e-mail: t2551040@eng.kitakyu-u.ac.jp, matsumoto-t@kitakyu-u.ac.jp).

A. Fujiyama is with Hokkaido University, Sapporo, 060-8628 Japan (e-mail: fujiyama@eng.hokudai.ac.jp).
Eco-town's enterprise call for quantitative understanding and analysis of major factors.

With this background, and given the fact that even more Eco-town enterprises are being initiated nationally, the present research is based on the long experience of Kitakyushu Eco-town, which was the first to sign the agreement back in 1997. Specifically, this research addresses changes in materials costs and transportation distance, based on two questionnaire surveys (conducted at two different points in time) and also interview to ascertain the flow data. In addition, factor analysis was conducted in relation to these changes, and the recycle initiative's $\mathrm{CO}_{2}$ reduction results were evaluated, in terms of life cycle assessment (LCA).

\section{RESEARCH METHODS}

\section{A. Prior Research}

Most of the prior research studies which quantitatively evaluate Eco-town materials circulation are based on fundamental research methodologies, MFA and LCA, and are of value, but in each case they are based on data from one point in time [8]. There is an Environmental Ministry survey which is multi-year, based on a comparison of investigations in 2008 and 2013 [9]. The study includes more than 170 enterprise locations, but the response ratio from the enterprises was only $50 \%$, thus making evaluation difficult. The number of enterprises providing data in both years was no more than 48. Turning to overseas locations such as EIP (Eco-industrial Park), Kalundborg [10], USA [11], the Netherlands [11], Tianjin [12], Ulsan [13], [14], Daedeok Technovalley [15], and Rio de Janeiro [16], research has been pursued on the development process, providing valuable quantitative data concerning the number of enterprise locations and related changes, but research is still lacking concerning specific materials flow data analyzed over time.

\section{B. Survey Methods}

Focusing on the Kitakyushu Eco-town enterprise locations, questionnaire surveys and interview were utilized twice, once in 2005 and again in 2010 [17], [18]. All enterprise locations in the Kitakyushu Eco-town were considered, but the totals for valid responses were as follows: for the 2005 survey (April to September), 18 of 21 total locations, and for the 2010 survey (January to March), 23 out of 28 total locations. Table I shows the valid response data for enterprises, organized according to the commodities they deal with.

Various factors led to changes in the number of valid responses from enterprise locations, such as enterprises newly entering the program or withdrawing from it, but the number of enterprises with valid responses in both the 2005 and 2010 
surveys totaled 15 .

The surveys included the following items:

1) quantity of waste material received from outside Eco-town

2) quantity of waste material received from within Eco-town

3) new inputs of materials for processing etc.

4) amount of energy use

5) amount of refurbished products and materials shipped from Eco-town

6) amount of refurbished products and materials shipped within Eco-town

7) amount of waste material discharged

8) amount discharged as waste water

Fig. 1 shows a visual representation of these measured items.

TABLE I: VALID RESPONSE DATA FOR ENTERPRISES (ACCORDING TO THE COMMODITIES THEY DEAL WITH)

\begin{tabular}{|c|c|c|}
\hline category & 2005 & 2010 \\
\hline plastic bottle & $1(1)$ & $1(1)$ \\
\hline mixed construction waste & $2(2)$ & $1(1)$ \\
\hline car & $1(2)$ & $1(2)$ \\
\hline electrical appliance & $1(1)$ & $1(1)$ \\
\hline OA equipment & $1(1)$ & $2(2)$ \\
\hline fluorescent & $1(1)$ & $1(1)$ \\
\hline medical supplies & $1(1)$ & $1(1)$ \\
\hline used paper & $1(1)$ & $2(2)$ \\
\hline cooking oil & $1(1)$ & $1(1)$ \\
\hline organic solvent & $1(1)$ & $1(1)$ \\
\hline pachinko machine & $1(1)$ & $1(1)$ \\
\hline food container & $2(2)$ & $2(2)$ \\
\hline waste wood - waste plastic & $1(1)$ & $1(1)$ \\
\hline recycling residue & $1(1)$ & $1(1)$ \\
\hline plastic & $1(1)$ & $1(2)$ \\
\hline toner cartridge & $1(1)$ & $0(0)$ \\
\hline nonferrous metal & $0(0)$ & $1(1)$ \\
\hline industrial waste & $0(0)$ & $2(2)$ \\
\hline food waste & $0(1)$ & $1(2)$ \\
\hline soil remediation & $0(0)$ & $1(1)$ \\
\hline wind power generation & $0(1)$ & $0(2)$ \\
\hline total & $18(21)$ & $23(28)$ \\
\hline
\end{tabular}

※total enterprise of itemized in bracket

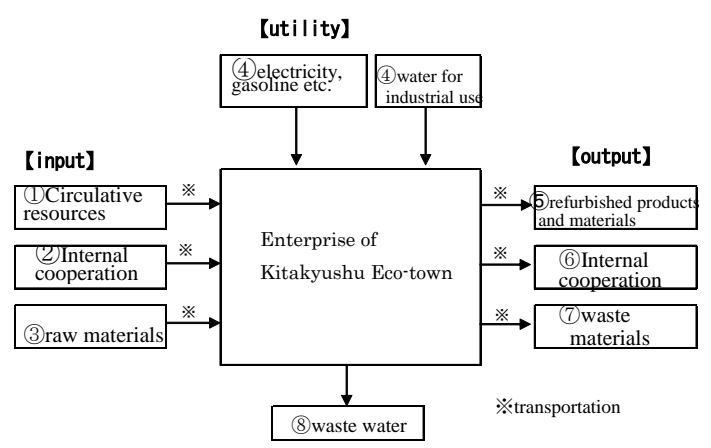

Fig. 1. Visual representation of these measured items.

However, items 2 and 6, which both deal with internal connections, were only included in the 2005 survey. These waste products etc. are indicators of waste and resource circulation, and refurbished products and materials are indicators of waste that has been processed for use.

\section{Changes In Materials Flow}

\section{A. Changes in Investment and Structures of Production}

The tabulated data from enterprises with valid responses is provided in Fig. 2 and 3. As for the Kitakyushu Eco-town enterprises' resource circulation inputs, the 2005 survey showed an annual amount of approximately 254,000 tons, and the outputs of refurbished products and materials totaled 219,000 tons; in contrast, for the 2010 survey the respective totals were 475,000 tons and 368,000 tons.

Comparing the changes in inputs and outputs, it can be seen that the 2005 results for resource circulation increased by about $87 \%$, and the produced quantities of refurbished products and materials increased by about $68 \%$.

\section{B. Changes in Transportation Quantities According to Distance}

The data from each of the enterprises were tabulated, sorted according to distance, and analyzed as seen in Fig. 4 and 5. Distance was measured using Kitakyushu Eco-town as the center, and categorized as less than $20 \mathrm{~km}, 50 \mathrm{~km}, 300 \mathrm{~km}$, $500 \mathrm{~km}, 1000 \mathrm{~km}$, and more than $1000 \mathrm{~km}$. Consequently, the categories correspond to areas within Eco-town, within Kitakyushu City, within Fukuoka Prefecture, within Kyushu, as far as Tokyo, and beyond Tokyo. On the input side, results increased except for the $50 \mathrm{~km}$ band and the $1000+\mathrm{km}$ group. For 2005 the $50 \mathrm{~km}$ band had the highest results, but in 2010 it was the $300 \mathrm{~km}$ band. On the other hand, for the production side, there were increases in all categories except for the $500 \mathrm{~km}$ band, and for both 2005 and 2010 the highest data were found in the $20 \mathrm{~km}$ category.

\section{CHANGES IN EFFECTS OF REDUCTION OF ENVIRONMENTAL BURDENS (LCA)}

Based on materials flow data from both 2005 and 2010, an analysis was carried out of $\mathrm{LCCO}_{2}$, and the results are shown in Fig. 6. Compared to results for 2005, 2010 data for the transportation process, the recycling process, waste product processing process all showed increases. The natural resources exchange results for the recycling process showed an $86.7 \%$ increase over the results for 2005 .

\section{AnAlysis OF StRUCtURAL CHANGES IN $\mathrm{CO}_{2}$ REDUCTION}

\section{A. Factor Analysis Inclusive of All Stages}

In order to conduct a factor analysis of $\mathrm{CO}_{2}$ emissions level changes, based on 2005 and 2010 materials flow data, a factor analysis model with the following intermediate term parameters was constructed.

First, the following identity was used to define $\mathrm{CO}_{2}$ emissions amounts based on the type of business involved.

$$
\mathrm{CO}_{2}=\sum_{i=1}^{6}\left\{\left(\frac{\mathrm{CO}_{2} i}{\mathrm{Mi}}\right) \times\left(\frac{\mathrm{Mi}}{\mathrm{Ri}}\right) \times R i\right\}
$$

Here, $\mathrm{CO}_{2}=$ Amounts of $\mathrm{CO}_{2}$ emitted;

$i=$ Type of business, numbered 1 to $7 ; M=$ annual emissions; $R=$ number of employees

Factors 1 to 3 are defined as follows.

(CO2 i)/Mi...Factor 1: Carbon accumulation 
Mi/Ri...Factor 2: Annual inputs per company employee Ri ...Factor 3: Inputs

Next, a differential equation (see below) based on Equation (1) was used to create a factor analysis model of changes in the amounts of carbon emissions. The results are shown in Fig. 7.

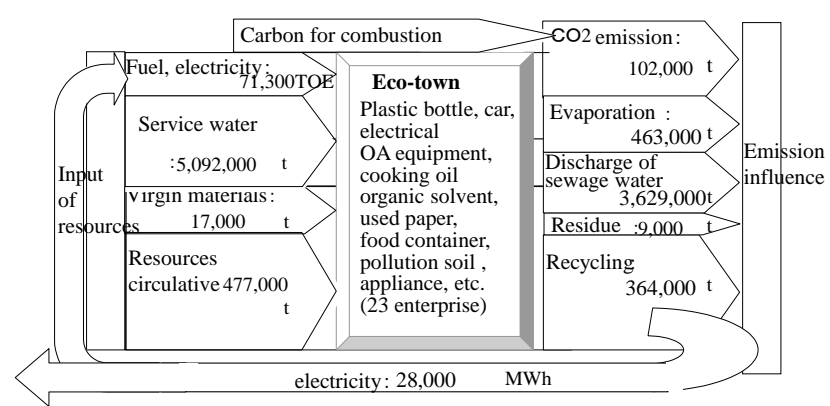

Fig. 2. Material flows in the Kitakyusyu Eco-town (2005).

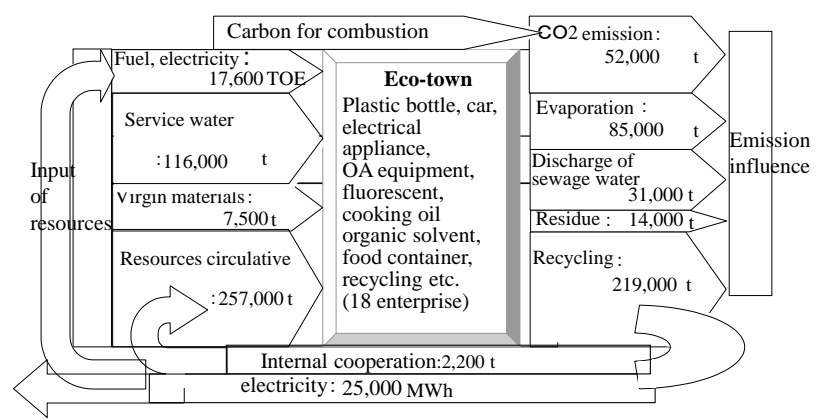

Fig. 3. Material flows in the Kitakyusyu eco-town (2010).

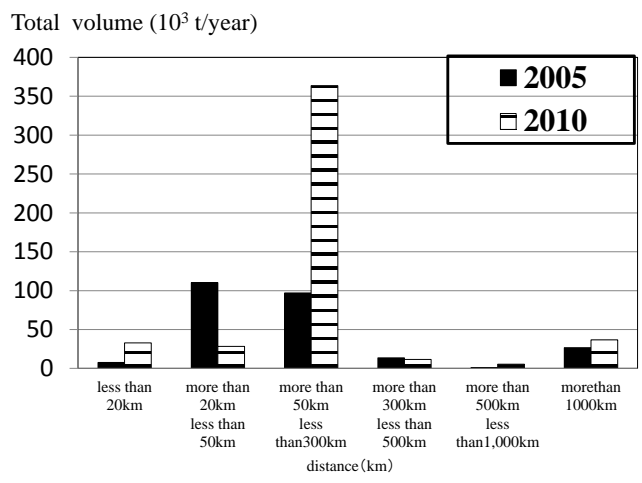

Fig. 4. Waste product inputs according to distance.

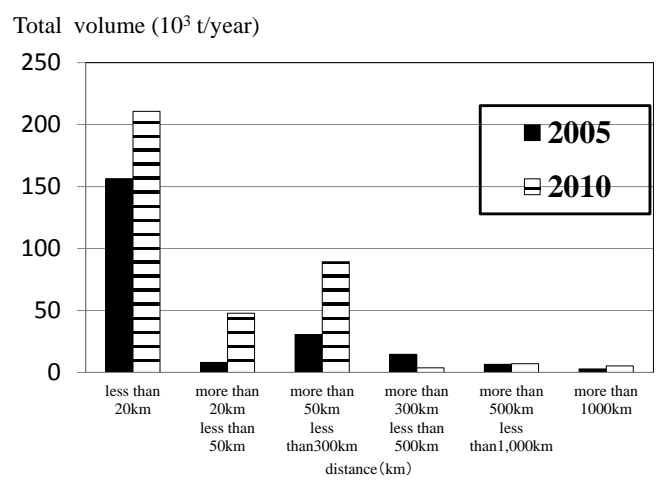

Fig. 5. Recycled material outputs according to distance.

From these results it was learned that the changes in carbon emissions for the electrical appliances and machines group showed a large reduction, amounting to 50,000 tons. In addition, the metallic waste category also showed large changes overall.

$$
\begin{aligned}
& \sum_{i=1}^{6}\left\{\left(\Delta \frac{\mathrm{CO}_{2} i}{\mathrm{Mi}}\right) \times\left(\frac{\mathrm{Mi}}{\mathrm{Ri}}\right) \times R i\right\} \\
\Delta C \mathrm{O}_{2}= & +\sum_{i=1}^{6}\left\{\left(\frac{\mathrm{CO}}{\mathrm{Mi}}\right) \times\left(\Delta \frac{\mathrm{Mi}}{\mathrm{Ri}}\right) \times R i\right\}+\text { residual term (2) } \\
& +\sum_{i=6}^{6}\left\{\left(\frac{\mathrm{CO} 2}{M i}\right) \times\left(\frac{M i}{R i}\right) \times \Delta R i\right\}
\end{aligned}
$$

\section{B. Factor Analysis of the Transportation Stage}

The following equation was proposed for the factor analysis of the transportation stage.

$$
C O_{2}=\sum_{i=1}^{6}\left\{\left(\frac{\mathrm{CO}_{2} i}{t i \times k m i}\right) \times\left(\frac{t i \times k m i}{t i}\right) \times\left(\frac{t i}{f i}\right) \times f i\right\}
$$

Here, $\mathrm{CO}_{2}=$ Amount of carbon emitted in transportation stage; $i=$ Type of business, numbered 1 to $6 ; t=$ Annual inputs; $k m=$ Shipping distance; $f=$ Shipping frequency.

Factors 1 to 4 were defined as follows.

$\left(\mathrm{CO}_{2} \mathrm{i}\right) /(\mathrm{ti} \cdot \mathrm{kmi}) \ldots$ Factor 1: Ton/kilometer units

(ti $\cdot \mathrm{kmi}) / \mathrm{ti}$...Factor 2: Transportation distance

ti/fi...Factor 3: Quantity per shipping instance

fi...Factor 4: Transportation frequency

Next, a differential equation was derived from Eq. 3, to establish the following factor analysis model of changes in $\mathrm{CO}_{2}$ emissions during the transportation stage. The results are shown in Fig. 8.

$$
\begin{aligned}
& \sum_{i=1}^{6}\left\{\Delta\left(\frac{\mathrm{CO}_{2} i}{t i \times k m i}\right) \times\left(\frac{t i \times k m i}{t i}\right) \times\left(\frac{t i}{f i}\right) \times R i\right\} \\
& +\sum_{i=1}^{6}\left\{\left(\frac{C \mathrm{CO}_{2}}{t i \times k m i}\right) \times \Delta\left(\frac{t i \times k m i}{t i}\right) \times\left(\frac{t i}{f i}\right) \times f i\right\} \\
& +\sum_{i=6}^{6}\left\{\left(\frac{C O_{2}}{t i \times k m i}\right) \times\left(\frac{t i \times k m i}{t i}\right) \times \Delta\left(\frac{t i}{f i}\right) \times f i\right\} \\
& +\sum_{i=6}^{6}\left\{\left(\frac{C O 2}{t i \times k m i}\right) \times\left(\frac{t i \times k m i}{t i}\right) \times\left(\frac{t i}{f i}\right) \times \Delta f i\right\}
\end{aligned}
$$$$
+ \text { residual term }
$$

Looking first at the totals, it can be seen that although all other factors increased, the first factor significantly decreased, meaning that overall carbon emissions decreased during the transportation stage.

Looking next at results according to business type, biomass and other waste matter showed large changes in quantity. The large change to the minus side for biomass can be attributed to the fact that although two companies had been added to the 2010 survey, one had a small quantity per shipment so that ton/kilometer measurements were reduced. A major influence in the large changes on the plus side for other waste products can be found in the fact that with four companies being added since 2005 four factors showed comparative increases. As for electrical appliances and tools, one of the companies involved showed an increase of about $30 \%$ in inputs, which in effect led to worse overall results. On the other hand, in the area of food 
containers one company showed about a $30 \%$ decrease in inputs, which was a major factor.

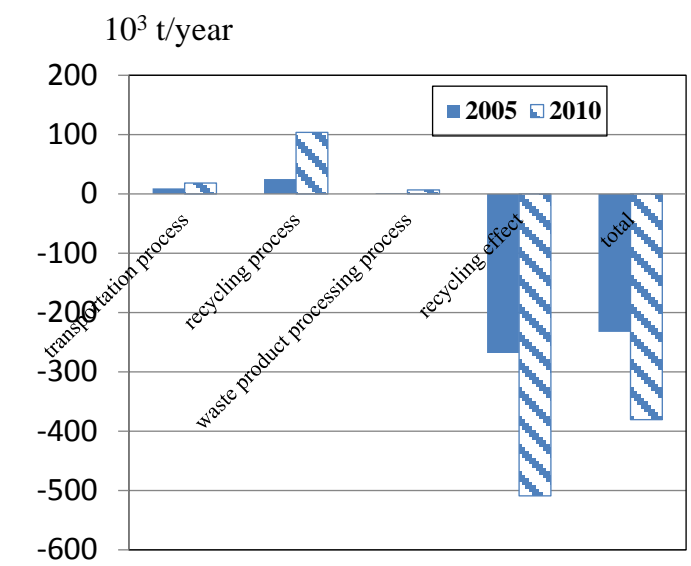

Fig. 6. Effects of $\mathrm{LCCO}_{2}$ reduction in the Kitakyusyu eco-town.

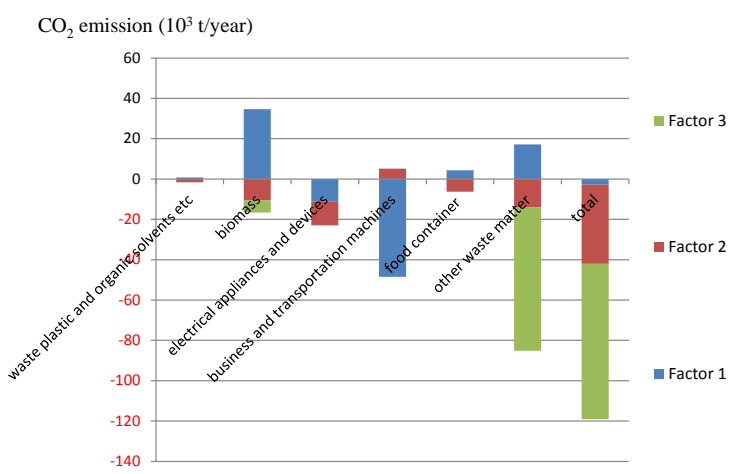

Fig. 7. Result of factor analysis of $\mathrm{CO}_{2}$ emission (all stages).

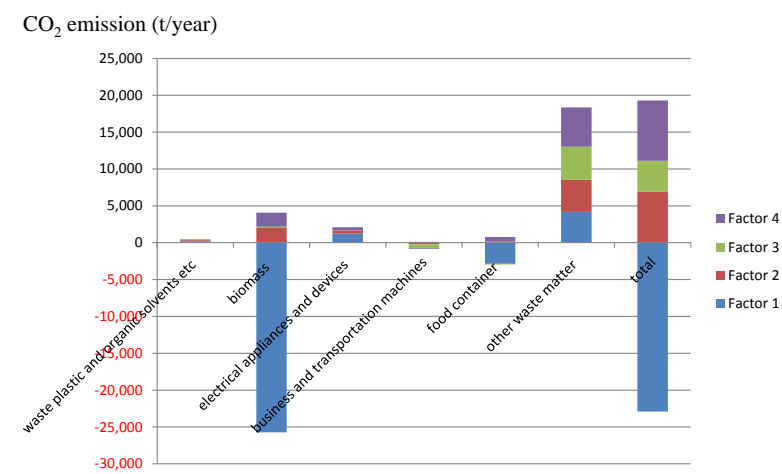

Fig. 8. Result of factor analysis of $\mathrm{CO}_{2}$ emission (transportation stage).

\section{Factor Analysis of the Recycling Processing Stage}

The factor analysis equation for the transportation stage was defined as follows.

$$
\begin{gathered}
\mathrm{CO}_{2}= \\
\sum_{i=1}^{6}\left\{\left(\frac{C O 2 i}{E i}\right) \times\left(\frac{E i}{M i}\right) \times M i\right\}
\end{gathered}
$$

Here, $\mathrm{CO}_{2}=$ the amount of $\mathrm{CO}_{2}$ discharged during recycling processing; $i=$ the business category involved (among 6 possibilities); $M=$ annual inputs; $E=$ energy consumed during recycling processing.

The three factors for analysis are defined as follows. $\left(\mathrm{CO}_{2} \mathrm{i}\right) /$ Ei...Factor 1: Extent of Carbon Accumulation Ei/Mi...Factor 2: Energy consumed per unit of inputs Mi...Factor 3: Quantity of inputs
As was the case with the transportation stage, Equation 5 was differentiated, yielding a factor analysis model of $\mathrm{CO}_{2}$ emissions changes related to the recycling processing stage, as shown below. The results are shown in Fig. 9.

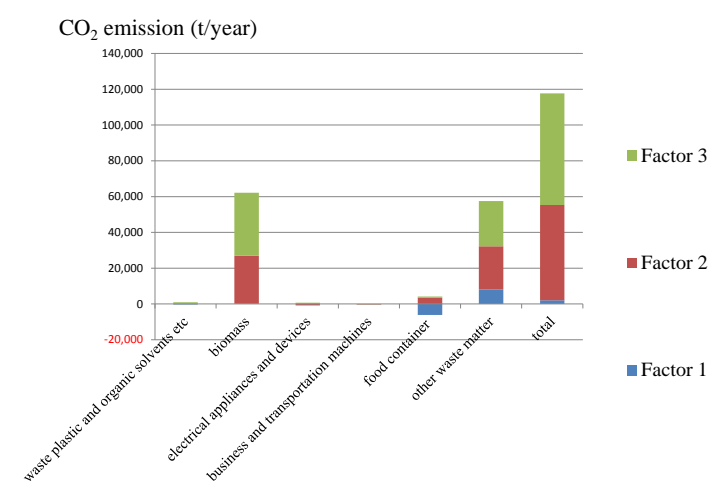

Fig. 9. Result of factor analysis of $\mathrm{CO}_{2}$ emission (recycling processing stage).

$$
\begin{gathered}
\Delta \mathrm{CO}_{2}= \\
\sum_{i=1}^{6}\left\{\left(\Delta \frac{C \mathrm{O}_{2} i}{E i}\right) \times\left(\frac{E i}{\mathrm{Ei}}\right) \times M i\right\} \\
+\sum_{i=1}^{6}\left\{\left(\frac{C \mathrm{O}_{2}}{E i}\right) \times\left(\Delta \frac{E i}{M i}\right) \times M i\right\} \\
+\sum_{i=6}^{6}\left\{\left(\frac{C O_{2}}{E i}\right) \times\left(\frac{E i}{M i}\right) \times \Delta M i\right\} \\
\text { +residual term }
\end{gathered}
$$

Looking first at the overall totals, it became evident that because Factors 2 and 3 showed large increases, the recycling processing stage overall also showed increases in $\mathrm{CO}_{2}$ emissions amounts.

Looking next at the business categories, it can be seen that there were large changes in $\mathrm{CO}_{2}$ emissions related to biomass and other waste products. Examining the various factors, it became evident that although the changes in Factor 1 were small, all other factors showed large changes.

As for the large changes in $\mathrm{CO}_{2}$ emissions for biomass and other waste products, and particularly concerning Factor 3, this was due to the large increase in annual inputs, as a result of the fact that 2010 saw two additional companies tied to biomass and four related to other waste products. Furthermore, as for Factor 2, both biomass and other waste products areas saw increases in energy expenditures per unit of inflow, due to a newly relocated enterprise with large energy expenditures.

Three business categories (waste plastic and organic solvents etc.; electrical appliances and devices; and business and transportation machines and tools) showed no changes in the number of enterprises between 2005 and 2010, and as a result there were no large changes in these factors. In the food container category, there was a slight change in $\mathrm{CO}_{2}$, but electric power consumption by one company increased greatly, and also gasoline began to be used, so both Factor 1 and Factor 2 showed changes.

\section{CONCLUDING REMARKS}

Japan's Eco-town Initiative, now in its 18th year, aims not only to play a leading role in the recycling industry, but also to 
continue in its role of providing a solid support for regional areas and the overall resource circulation system. Therefore, as we pointed out in the introduction, we are seeking mid- and long-term verification of results. The current research, by means of investigation and comparison of multi-year datasets, was able to demonstrate not merely conditions at a single point in time, but rather the quantitative changes affecting $\mathrm{CO}_{2}$ emissions over time, in accordance with changes in enterprises' activities.

By examining the multi-year production flow data, we were able to gain a quantitative understanding of the changes in the number of businesses located in Eco-town and their respective inputs and outputs of waste products, refurbished products and materials, etc.

Based on an analysis of the inputs and outputs associated with the transportation structure, it was also possible to clarify the changes with the greatest influence; in the case of Kitakyushu Eco-town, this meant grasping the roles played by resource circulation in a comparatively broad $300 \mathrm{~km}$ range, as well as those of the businesses involved and their clients.

Conclusions were also reached based on an analysis of factors relevant to whether the businesses participated in both or only one of the two surveys (2005 and 2010). It was established that a large influence could be found in relation to those enterprises which either left the area during this time or newly located in the area, causing changes in the inflow/output structure and transportation distance.

We are also further aware that as a future research objective it will be necessary to analyze the stability of the Eco-town resource circulation facilities.

\section{ACKNOWLEDGMENT}

We wish to express our gratitude to those from the businesses in Kitakyushu Eco-town and the Environmental Bureau of the city government of Kitakyushu, who kindly cooperated in providing information for this study.

\section{REFERENCES}

[1] H. Shi, J. Tian, and L. Chen, "China's quest for eco-industrial parks, Part I: History and distinctiveness," Journal of Industrial Ecology, vol. 16, issue 1, pp. 8-10, 2012.

[2] P. Laybourn and D. R. Lombardi, "Industrial symbiosis in European policy: Overview of recent progress," Journal of Industrial Ecology, vol. 16, issue 1, pp. 11-12, 2012.

[3] F. Boons and W. Spekkink, "Levels of institutional capacity and actor expectations about industrial symbiosis: Evidence from the Dutch stimulation program 1999-2004," Journal of Industrial Ecology, vol. 16, issue 1, pp. 61-69, 2012.

[4] R. L. Paquin and J. H.-Grenville, "The evolution of facilitated industrial symbiosis," Journal of Industrial Ecology, vol. 16, issue 1, pp. 83-93, 2012.

[5] G. F. Brent, D. J. Allen, B. R. Eichler, J. G. Petrie, J. P. Mann, and B. S. Haynes, "Mineral carbonation as the core of an industrial symbiosis for energy-intensive minerals conversion," Journal of Industrial Ecology, vol. 16, issue 1, pp. 94-104, 2012.

[6] L. Zhou, S.-y. Hu, Y. Li, Y. Jin, and X. Zhang, "Modeling and optimization of a coal-chemical eco-industrial system in China," Journal of Industrial Ecology, vol. 16, issue 1, pp. 105-118, 2012.

[7] O. Salmi, J. Hukkinen, J. Heino, N. Pajunen, and M. Wierink, "Governing the interplay between industrial ecosystems and environmental regulation: Heavy industries in the gulf of Bothnia in Finland and Sweden," Journal of Industrial Ecology, vol. 16, issue 1, pp. 119-128, 2012.

[8] S. Fujita, E. Nagasawa, S. Onishi, and S. Sugino, "Evaluation system for policy scenario of industrially symbiotic technologies in Kawasaki eco-town," Environmental systems research, vol. 35, pp. 89-100, 2007.

[9] S. Ohnishi, M. Fujii, T. Fujita, T. Matsumoto, L. Dong, H. Akiyama, H. Dong, "Comparative analysis of recycling industry development in Japan following the eco-Town program for eco-industrial development," Journal of Cleaner Production, April 2015.

[10] N. B. Jacobsen, "Industrial symbiosis in Kalundborg: A quantitative assessment of economic and environmental aspects," Denmark Journal of Industrial Ecology, vol. 10, issue 1-2, pp. 239-255, 2006.

[11] R. R. Heeres, W. J. V. Vermeulen, and F. B. de Walle, "Eco-industrial park initiatives in the USA and the Netherlands: First lessons," Journal of Cleaner Production, vol. 12, issues 8-10, pp. 985-995, 2004.

[12] H. Shi, M. Chertow, and Y. Song, "Developing country experience with eco-industrial parks: A case study of the Tianjin economic-technological development area in China," Journal of Cleaner Production, vol. 18, issue 3, pp. 191-199, 2010.

[13] H.-S. Park, E. R. Rene, S.-M. Choi, and A. S. F. Chiu, "Strategies for sustainable development of industrial park in Ulsan, South Korea From spontaneous evolution to systematic expansion of industrial symbiosis," Journal of Environmental Management, vol. 87, issue 1, pp. 1-13, 2008.

[14] S. K. Behera, J.-H. Kim, S.-Y. Lee, S. Suh, and H.-S. Park, "Evolution of 'designed' industrial symbiosis networks in the Ulsan Eco-industrial Park: 'research and development into business' as the enabling framework," Journal of Cleaner Production, vol. 29-30, pp. 103-112, 2012.

[15] D.-S. Oh, K.-B. Kim, and S.-Y. Jeong, "Eco-industrial park design: A daedeok technovalley case study," Habitat International, vol. 29, issue 2, pp. 269-284, 2005.

[16] L. B. E. Veiga and A. Magrini, "Eco-industrial park development in Rio de Janeiro, Brazil: A tool for sustainable development," Journal of Cleaner Production, vol. 17, issue 7, 2009, pp. 653-661

[17] Toru Matsumoto, "Progress and evaluation of Kitakyushu EIP as a resource recovery model," Summary and Proceedings of the Asia-Pacific International Workshop on Industrial Ecology, pp. 28-29, 2008.

[18] T. Matsumoto, E. Katsuhara, T. Tsuruta, and K. Hujiyama, "Comprehensive assessment in effect of environmental road reduction of regional resource circulation base," Environmental Systems Research, vol. 37, pp. 321-329, 2009.

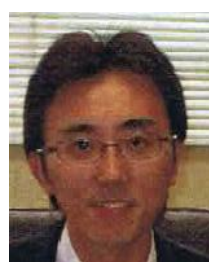

Tadashi Tsuruta is the president of Environmental Technology Service Corporation. His study fields are assessment of effect for the resources circulation system, especially the case study of Kitakyushu Eco-town. $\mathrm{He}$ is also the $\mathrm{PhD}$ candidate of the University of Kitakyushu.

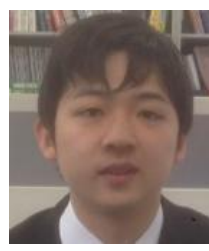

Yuki Honda is undergraduate student at the University of Kitakyushu, Japan.

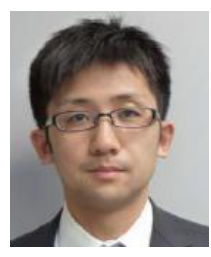

Atsushi Fujiyama is a research associate at the Hokkaido University, Japan. He received his B.A. (2009), M.Eng. (2011) and D.Eng. (2013) from the University of Kitakyushu, Japan.

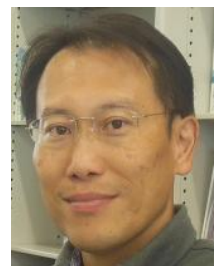

Toru Matsumoto is a professor at the University of Kitakyushu, Japan. He received his B.A. (1990), M.Eng. (1992) and D.Eng. (1999) from Kyushu University, Japan. He worked as a researcher for Nomura Research Institute (NRI), one of the biggest think tanks in Japan, between 1992 and 1995. He was a research associate of Kyushu University from 1995 until 1999 and an associate professor of Kyushu University and the University of Kitakyushu from 2000 until 2008. 